ENTREPRENEURSHIP AND SUSTAINABILITY ISSUES

ISSN 2345-0282 (online) http://jssidoi.org/jesi/

2019 Volume 6 Number 3 (March)

http://doi.org/10.9770/jesi.2019.6.3(10)

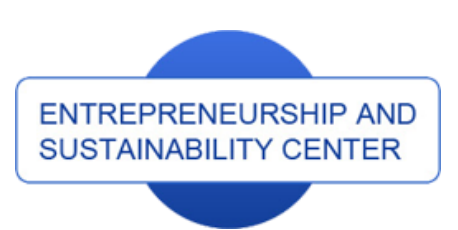

Publisher

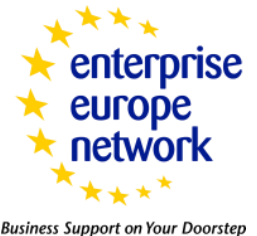

CASPA

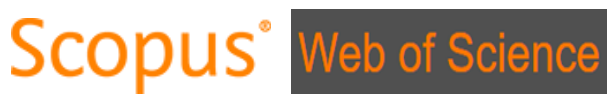

http://jssidoi.org/esc/home

Business Support on Your Doorstep

1) Clarivate

Analytics

\title{
CONTENT OF A INTRA GROUP COMPLIANCE AGREEMENT AS A RISK MITIGATING FACTOR
}

\author{
Marek Kordík ${ }^{1}$ Lucia Kurilovská ${ }^{2}$ \\ 1,2 Department of the Criminal law, Criminology and Criminalistics \\ Faculty of Law, Comenius University in Bratislava, Šafárikovo nám. 6, P.O.BOX 313, 81000 Bratislava, Slovakia \\ E-mail: marek.kordik(at)flaw.uniba.sk
}

Received 20 June 2018; accepted 25 November 2018; published 30 March 2019

\begin{abstract}
The contribution deals with the topic of relationship between the mother company and the daughter company, specifically how to set up, control and verify the compliance rules in the daughters company acc the standards important for the mother company. Current legal and managerial environment require to implement the same lavel as applied by the mother company not only to protect its shares in the subsidiaries but more likely to create a shelter and mitigate possible risk for the conduct of its subsidiary in its country, culture and environment. The contribution shows the possibility to implement the compliance rules and the compliance manangemtn systemof the mother company in the daughter company through the so-called intragroup agreement as a frame to set up a correct control, reporting, consequence management in the daughter company. It also draws a line how the compliance should be taken in the subsidiary in relation to the position of created compliance office, that needs to be stablished and manged in the separate line stream form the line management to ensure its independence. The authors show the relevance of this model also by particular decision of the legal practice, mainly quoting plea bargaining of the accused legal persons from corruption or moneylaundering conducts.
\end{abstract}

Keywords: compliance; effectiveness; criminal responsibility; post-acquisition; SPV; sanctions; vulnerability; mother-company; daughtercompany; intra group relations.

Reference to this paper should be made as follows: Kordík M. Kurilovská, L. 2019. Content of a IntraGroup Compliance Agreement as a risk mitigating factor Entrepreneurship and Sustainability Issues 6(3): 1195-1204. http://doi.org/10.9770/jesi.2019.6.3(10)

JEL Classifications: M14, M16

Additional discipline: law, risk management, compliance.

*This work was supported by the Slovak Research and Development Agency under the contract No. APVV-150267 


\section{ENTREPRENEURSHIP AND SUSTAINABILITY ISSUES}

ISSN 2345-0282 (online) http://jssidoi.org/jesi/

2019 Volume 6 Number 3 (March)

http://doi.org/10.9770/jesi.2019.6.3(10)

\section{Introduction}

This article follows an article Intra Group Compliance Agreement as a tool to manage the risks in the daughter companies (Kurilovská, Kordík, 2018) to give an deeper analyses on the content of the Intragroup compliance relationship in particular what are the roles and functions of the mother company that is requesting the implementation of the compliance management system and the daughter company that is requested to cooperate (Reitzel, 1990, p.225).

Ethics \& Compliance and Law Violations may be defined as serious illegal or unethical behavior, violations of civil or criminal law, or company' Code of Conduct or related policies, or other significant misconduct. Examples include but are not limited to actual or threatened physical violence, theft, intentional or reckless fraud, corruption, bribery, kickbacks, conflicts of interest, accounting irregularities, misleading accounting personnel or internal or external auditors, interfering with or obstructing internal investigations, discrimination, harassment, circumvention of internal controls, disclosing confidential information, breach of customer or employee privacy, falsification of company records (including expense reports), violation of accounting policies, unauthorized or undisclosed commitments, side letters, violation of import/export regulations, abuse of company resources, etc. Whether an act of alleged misconduct constitutes a potential Ethics \& Compliance and Law Violation will be determined by the findings of the company (Statement of offense Siemens AG v. USDOJ, 2013, para 33-35). All credible and actionable allegations of Ethics \& Compliance and Law Violations in the corporations need to be taken seriously and need to be investigated in a professional, competent, fair, objective, impartial, confidential, lawful and timely manner (Anderson, Grey 2006, p.105).

Depending on applicable law, and in consultation with workers' representatives (where applicable), this may include such things as: (Statement of offense Siemens AG v. USDOJ, 2013, para 36-61).

- keeping confidential the fact and subject of the investigation, as well as information, documents or other evidence provided to Company Investigators;

- responding truthfully, accurately and completely to questions from Company Investigators;

- thoroughly and timely complying with requests from Company Investigators for email, documents and other evidence; preserving emails, documents and other evidence that may be relevant to the investigation;

- turning over and/or providing access to company-provided workspaces, computers, communication devices, desks, filing cabinets, and other company-provided equipment or property; and

- if necessary and warranted under the circumstances, and permitted under local law, providing reasonable access to personal property and documents brought onto company premises or stored on companyprovided computers or other devices.

- to search, inspect, and monitor company-provided resources including buildings, workspaces, vehicles, desks, filing cabinets, company-provided information and technology resources (such as computers and communications devices), and other company-provided equipment or property, and to access, intercept, copy, review, disclose and delete any communications, files, websites or data access, send, receive, create or maintain with or in company resources.

From the above mentioned it is evident, that the compliance and corporate investigation in particular is a complex process consisted of a legal, organizational, HR and informational puzzles. It is even more complicated if the corporation needs to/is willing to establish the compliance management system and corporate investigation in its subsidiaries and to cascade the whole system a level below. To create an effective and vivid compliance management system it is essential to establish the information exchange and flow from the subsidiary towards the Mother Company and vice-versa. (Plea agreement, Kellog, Brown, Root, LLC. V. USDOJ, 2011, para. 25) One possibility how to reach it, is to establish the cooperation through the so-called Intra Group Compliance 


\section{ENTREPRENEURSHIP AND SUSTAINABILITY ISSUES}

ISSN 2345-0282 (online) http://jssidoi.org/jesi/

2019 Volume 6 Number 3 (March)

http://doi.org/10.9770/jesi.2019.6.3(10)

Agreement (further as "IGCA"). Its content, purpose and characteristics is provided bellow. (Statement of Offense, Siemens AG v. USDOJ, 2013, para 8-9).

\section{Services provided by the Mother Company without the subsidiary request}

The Mother Company shall provide the following services without a separate call-off by the subsidiary in the design and operation of its compliance organization.

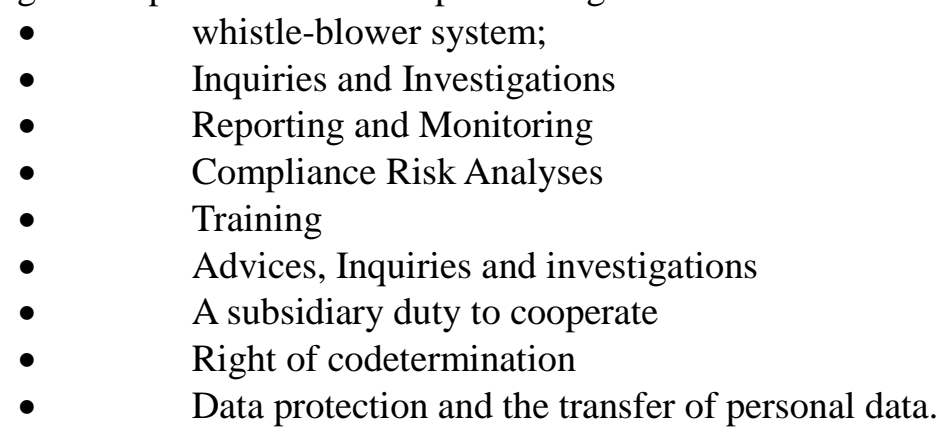

\section{Mother Company whistle-blower system}

The Company needs to hear about suspected Ethics \& Compliance and Law Violations involving employees, employees of any subsidiary, contingent workers, or third parties performing services on company behalf. (Statement of Offense, Siemans AG v. USDOJ, 2013, para 86) To that end, if the whistle-blower suspects that any company employee, contingent worker or third party performing services on company' behalf is or maybe engaging in an Ethics \& Compliance and Law Violation, the company should strongly encouraged and, depending on the role and country, may be required, to bring these concerns to the company (Statement of Offense SIEMENS AG v. USDOJ, 2013, para 74).

On the other hand, one shall not make the false reports or use the reporting process for inappropriate purposes, such as to harass, slander or humiliate others, or to interfere with or obstruct an internal investigation. Reports should be based on a sincere concern that an Ethics \& Compliance, Law Violation or other misconduct may have occurred and should not be based on prejudice or mere speculation. Even good faith reports must be made confidentially and by appropriate means. This is to protect the integrity of the process and the reputations of the accused and others involved in the investigation who are entitled to be treated fairly and with dignity and respect. It is not appropriate to widely disseminate allegations internally or externally via broadcast emails or other disruptive means. Individuals who knowingly make false reports or who misuse the reporting process by making reports for inappropriate purposes or by using inappropriate means, need to be subject to the discipline and other consequences provisions. However, any individual who makes a good faith report of suspected misconduct (i.e., a report that he or she reasonably believes to be true) will not be subject to discipline or other consequences even if the underlying concern turns out to be unfounded or could not be substantiated after investigation (Resource Guide to the FCPA, 2012, p. 82).

If the Mother Company operates a whistleblowing system (usually a mailbox, hotline, the employeses should use the means, wich are the most comfortable), it should be agreed in the IGCA that the tip-offs can be submitted at any time and the whistleblower's anonymity is technically maintained (if desired in the individual case); information is treated as confidential. 


\section{ENTREPRENEURSHIP AND SUSTAINABILITY ISSUES}

ISSN 2345-0282 (online) http://jssidoi.org/jesi/

2019 Volume 6 Number 3 (March)

http://doi.org/10.9770/jesi.2019.6.3(10)

If the tip-offs are not related to compliance violations of relevance to the Group, but related to the Mother Company, it should be agreed the Mother Company shall according the IGCA forward them to the subsidiary after subjecting them to a plausibility check (US Sentencing Commission Guideline Manual, 2014, Part 8B2.1).

If no action is taken or if there is a conflict of interest, the tip-offs shall be directed to the member of the subsidiary's management responsible for compliance. The subsidiary reports the results, including meaningful and verifiable documentation, in accordance with the IGCA to the Mother Company after final processing of the tipoff at the latest. The subsidiary should also submit interim reports on request (Reitzel, 1990, p. 342-343).

\subsection{Reporting and Monitoring}

The Mother Company should have the possibility acc. the IGCA to address its own findings and recommendations for action to subsidiary's management or the bodies, committees or persons legally responsible for its supervision, provided that the Mother Company deems this action to be necessary in the individual situation. With regard to the monitoring of success stated above as well the results arising from the investigations in the cases of the Group relevance cases on the other hand, the Mother Company has a duty to report. The Mother Company shall report results of success monitoring, inquiries or any other situations requiring a decision by the subsidiary management or Supervisory Board to the member of subsidiary's management responsible for compliance.

If the responsible member of the Management fails to take action or has a conflict of interest, the IGCA should state the Mother Company shall direct its reports to all subsidiary managers with the exception of the member of the Management who has the conflict of interest. The Mother Company shall also be entitled to involve the subsidiary's Supervisory Board. If the Management as a whole fails to take action or has a conflict of interest according the IGCA the Mother Company shall direct its report to the appropriate supervisory body or its responsible committee members (e.g., Chairman of the Supervisory Board, General and Audit Committee of the Supervisory Board).

The Mother Company shall furthermore be entitled pursuant the IGCA to submit periodic reports directly to the Management as well as to the supervisory body or its committees at any time. (Turayová, Tobiašová, 2014, p.82)

To assist subsidiary's management in meeting its responsibilities in compliance matters and to ensure a uniformly high standard of compliance throughout the Group, the IGCA shall anticipate the Mother Company shall, at its own discretion, regularly check the operational implementation, suitability, completeness and effectiveness of the measures taken in operating the compliance management system of the subsidiary and in implementing the compliance program in the subsidiary (Anderson, Gray, 2006, p.105).

In line with the domestic law the Mother Company a comprehensive right to information. In doing this, the Mother Company shall be acc. the IGCA able to submit petitions to the subsidiary, either alone or - to the extent permitted by law - together with third parties it has engaged (e.g., attorneys-at-law, auditors) or other corporate departments of the Mother Company for the inspection of or request for information of any type whatsoever and to obtain information locally or by way of remote access. The Mother Company will grant that each submitted request for information will be in the line with its law and its Code of Conduct. The Mother Company should take full liability for any potential breach of its law by submitting such a request. The Mother Company access to its own information for this purpose, regardless of the format and systems used, as well as a direct right to ask questions of and receive answers from subsidiary's management and all employees of the subsidiary. Subsidiary's management according the IGCA shall support these measures and instruct its employees to cooperate with the Mother Company (Fenyk, Smejkal, 2012, p. 45).

IGCA should include the provisions related to the subsidiary obligation to prepare a compliance report which provides information on compliance violations within the subsidiary which meet the aforementioned criteria of a 
The International Journal

ENTREPRENEURSHIP AND SUSTAINABILITY ISSUES

ISSN 2345-0282 (online) http://jssidoi.org/jesi/

2019 Volume 6 Number 3 (March)

http://doi.org/10.9770/jesi.2019.6.3(10)

relevance offended in particular period of time.. In addition it should be established that the report should include a description of the case, information shall also be provided on the latest status of the measures taken.

If the Mother Company is at risk of incurring significant tangible or intangible damage, an ad hoc report shall be prepared.

The compliance report shall also contain statistics/KPIs and information on ways to enhance the Compliance Management System. (McCarthy, Bagby, 1990, p. 790)

Nevertheless the Mother Company should grant to the subsidiary employees and management all the rights to which they are entitled by the domestic law and collective labor agreement (if applied) mainly, but not limited to, the right to privacy, data protection and equal treatment. The Mother Company should grant the right to the employee deny to answer if such an answer could lead to the breach of commercial secret, telecommunication secret, bank secret, tax or duty secret. The Mother Company should not deny the right to the employee to deny to answer if the subject of the answer is considered confidential. If the prior consent of the third party or touched person is needed for the reveal of the information, the Mother Company, as anticipated in the IGCA grants the right to the employee to dismiss such a request if the consent has not been given. In the line with the IGCA the Mother Company shall grant to the employee to dismiss the answer, if it could lead to self- incrimination.

\subsection{Advices, Inquiries and Investigations}

It is worthy to establish that the subsidiary may request the support services as needed by submitting a request to the Mother company. IGCA should provision to the extent permitted by law and justifiable in fact, that the Mother Company shall support COMPANY as needed during the course of inquiries and investigations into possible compliance violations on the basis of corresponding reports or request on the part of the subsidiary which do not reach the threshold of "Group relevance" as defined.

If the subsidiary would like to use the corresponding expertise and resources of the Mother Company in conducting inquiries and investigations, and if the Mother Company is able to provide support, the IGCA should address the Mother Company shall be responsible for determining the type and scope of the services to be provided. The subsidiary shall be involved in the procedure at an early point. If the investigations are to be conducted with the involvement of third parties, the Parties shall initiate an appropriate engagement procedure and adhere to the applicable processes (Muller, Kalin, Goldsworth, 2007, p.813).

The Parties shall subsequently jointly work out the specific design of these services following submission of the request. (Aplikace $\S 8$ ods. 5, 2016) Depending on the type of misconduct being investigated, the Mother company may assign usually subject matter experts from e.g. Human Resources, Security, Legal, Finance, Corporate Audit, Information Security teams, to serve as Company Investigators or to assist the company investigators.

It should be stated, that in the event of justified initial suspicion of possible compliance violations within the subsidiary which have reached the threshold of Group relevance anticipated in the IGCA, the subsidiary shall facilitate and support the inquiries to be conducted by the Mother Company or by third parties it has engaged. The IGCA should address following situations shall be viewed as relevant for the Group: (US Sentencing Commission Guideline Manual, 2014, Part 8B2.1)

- Compliance violations in which a member of an executive body (Board of Management, managing directors, Supervisory Board) or the first or second reporting level is involved;

- Financial reporting or auditing of financial statements is affected;

- There is a risk of significant tangible or intangible damage;

- The damage exceeds particular thresholds in Euro; or

- Events deemed to be of relevance to the Group Board of Management, the board member responsible for Data Privacy, Legal Affairs and Compliance at The Mother Company or the COO. 
For the purpose of conducting such inquires, the subsidiary grants the Mother Company the rights for the information. The subsidiary will grant that it actively pursue all tip-offs of compliance violations and - if these are of relevance to the Group - submit them to the Mother company, along with meaningful and verifiable documentation acc. the IGCA. As stipulated in the IGCA the Mother Company grants its subsidiary that the Mother Company will be performed to the extent limited by the domestic law and can be conducted only in the line with the law. It is wise to provision that in the case of dispute, the subsidiary will provide the Mother Company with detail binding inquiry guidelines that shall not be exceeded. (Mac Adams, 1989, p. 891)

Based on mutual trust established by the IGCA, the subsidiary will grant the Mother Company that every executed request for information will be fully in the line with the domestic law and Code of Conduct. The IGCA should state that the subsidiary will take full responsibility for any potential breach of domestic law.

The Mother Company grants to provide the subsidiary detailed service level agreement (further mentioned as "SLA") about the, terms but not limited to:

- facilitation and support process of the Mother Company inquiry;

- justified initial suspicion;

- Events deemed to be of relevance to the Group Board of Management, the board member responsible for Data Privacy, Legal Affairs and Compliance at Mother Company or the COO. (Stessens, 2002, p.460)

The IGCA should also include the advisory lines and the possibility to ask for the opinion if needed. The Mother Company should operate a central consultation desk for providing personal advice to employees on compliance matters, which serves as a central portal for subject areas defined by the Mother Company..

Since the subsidiary operates its own consultation desk (if applicable), the Mother Company should grant to provide information as needed on the methodology and infrastructure for operating a portal of this type.

\subsection{Compliance Risk Analyses}

The IGCA should incorporate that Mother Company shall provide its subsidiary with advice and support in preparing a so-called Compliance Risk Analyses for evaluating its company-specific compliance risks and developing the company compliance program. For this purpose, the Mother Company shall describe the methodology, roles and responsibilities for compliance risk assessment and, in addition, provide overviews, checklists and reports on the experience of other companies which are comparable to the subsidiary. The Mother Company shall in the line with the IGCA subject the results to a plausibility check. The subsidiary shall grant to implement the recommendations derived therefrom on its own responsibility and as it sees fit. (Statement of Ofense Siemens AG v. USDOJ, 2013, para 74)

\subsection{Training}

The IGCA should emphasize the role of the education. It should be stated the Mother Company shall advise and support the subsidiary in carrying out the training it is responsible for providing to its managers and employees. It is worthy to anticipate, only those individuals who have been trained on the Internal Investigation Procedures should be assigned to serve as Company Investigators in connection with an internal investigation of potential Ethics \& Compliance, Law Violations. No one, including members of management, members or anyone else, should engage in internal investigatory activities relating to suspected Ethics \& Compliance, Law Violations unless they have been specifically assigned by the Mother Company or by the subsidiary. 
The International Journal

ENTREPRENEURSHIP AND SUSTAINABILITY ISSUES

ISSN 2345-0282 (online) http://jssidoi.org/jesi/

2019 Volume 6 Number 3 (March)

http://doi.org/10.9770/jesi.2019.6.3(10)

\subsection{A subsidiary duty to cooperate}

Within the scope of the services established in the IGCA to be provided by the Mother Company, the subsidiary shall support the Mother Company to the best of its abilities and in the line with the domestic law. The subsidiary shall establish the necessary prerequisites to enable the Mother Company to provide its services. For this purpose, the subsidiary shall, to the best of its abilities, take steps, among other things, to obtain any decisions of the executive bodies that may be needed (Management, supervisory committees or shareholders), prepare and announce instructions and guidelines for its employees, etc. (Gray, Hellman, Rytermann, 2004, p.81)

The subsidiary shall have the possibility to dismiss the cooperation if the request or ask for cooperation would lead to the breach of domestic law or the granted rights of the touched persons mainly, but not limited to the employees, business partners or third parties. The subsidiary should grant in accordance that every executed request for information is fully in the line with the domestic law and Code of the Conduct. The subsidiary shall take full responsibility for any potential breach of law (Deutscher Corporate Governance). One of the crucial point of the IGCA that needs to be addressed is the implementation of the group policies to assure the same level of compliance maturity. The Mother Company shall support its subsidiary with regard to the formal processes (e.g., need for committee decisions, implementation experience) in implementing the Mother Company policies. The IGCA should be accurate on one side in the fact that the subsidiary grants the rights to implement the Mother Company Policies in the way compatible with the domestic law and domestic business standards. Nevertheless the IGCA should as well consider that the local implementation of the Mother company policies shall not be against the primary meaning and purpose and has to follow its sense- to reach the same level of compliance maturity as achieved in the Mother Company (FATF, 40 reccomendations, 2017). The IGCA should equally cover also the subsequent situation when the subsidiary is a parent company, it shall take steps within its business units (BUs) to set up, implement and operate a Compliance management system which are tailored to the individual needs of the BU concerned.

\subsection{Right of codetermination}

It has to be provisioned in the IGCA that the subsidiary's management shall grant the Chief Complince Officer of the Mother Company s functional control over the Compliance Officer of the subsidiary. The Chief Compliance Officer of the Mother Company shall have the right to nominate a candidate. In the event of escalation, a decision shall be made at Board of Management level. It needs to be provisioned that a dismissal or termination of a Compliance Officer shall require the prior consent of the Chief Compliance Officer of the Mother Company in order to be effective.

\subsection{Data Protection}

To protect the integrity of internal investigations and the reputation and privacy of those involved, all internal investigations must be conducted confidentially. Company investigators and others involved in internal investigations should not disclose the fact or subject of, any details relating to, or the identities of accused individuals or other involved persons, except to those with a legitimate need to know based on their unique requirement to be involved in the case. All accused individuals and others involved in internal investigations must be treated fairly and with dignity and respect, in accordance with applicable law and in consultation with authorized workers' representatives (where applicable).

IGCA should incorporate a necessity to specify in the line with the data privacy legislation (law, Non-disclosure Agreements, Service Level Agreements, amendments of the labor contracts, consents oft he touched persons) if personal data is collected, processed or used during the aforementioned activities performed by the subsidiary. The IGCA should anticipate following: (US Sentencing Commission Guideline Manual, 2014, Part 8B2.1) 


\subsection{Data transmission.}

Any information shared among the subsidiary and the Mother Company within the provisions of this agreement is to be handled as confidential and is protected from disclosure to third parties. The subsidiary and the Mother Company should take all necessary steps to protect the applicable privilege and/or confidentiality of information received from the other, including ensuring that information received is not disclosed to anyone without the authorization of the disclosing party and/or unauthorized access in prevented. The information should be used only for the purpose described hereto and the Mother Company and the subsidiary shall abstain from using it for any other purpose.

\subsection{Right for the Information.}

The Mother Company should grant the right to the subsidiary to inform the minor shareholders of subsidiary about the content and nature of all information provided to the Mother Company. Mother Company should grant to provide the subsidiary with the result of the conducted inquiry that shall be passed to the minor shareholders of the subsidiary together with all necessary information.

\section{Conclusions}

Like many types of contractual arrangement, often only becomes apparent when something goes wrong. In everyday company life the concerns may raise from peers or collegues. Whenever a member of management or of the Human Resources, Legal, Security, Finance, Accounting, Audit or the various Internal Use Confidential compliance-related functions should be notified of a potential Ethics \& Compliance Violation as described above, he or she should refer it immediately to the Compliance office.

Concerns may pop up also in the course of internal processes. Potential Ethics \& Compliance Violations may become apparent in the course of handling internal matters such as personnel issues, safety investigations, fraud investigations, security incidents, accounting determinations, internal audits, control self-assessments or other internal activities.

Last but not least the concerns may origin from external processes. Similarly, potential Ethics \& Compliance Violations may also become apparent when responding to actual or threatened litigation, government inquiries and investigations, arbitrations or similar proceedings. When this occurs, the Compliance office should be notified immediately so the matter can be evaluated. Depending on the circumstances, the Compliance office may assume responsibility for the investigation or may partner with or defer to the team already handling the matter.

All these tip offs need to be taken seriously with respect to all relevant risks and being in compliance with all legal provisions.

Considering all these aspects, the effective compliance management system is a dance between eggs and may work only when it is set up properly and in time. On the other hand this does not necessarly mean adopting large number of robust internal policies creating a complicated administrative and reporting lines, processes, establishing cooperation and data protection agreements, e learnings etc. Even the small companies operate effective and high standard compliance manangment systems based on "open door policies and mutual trust"without any major internal regulations.

If one needs to draw a compliance management system from the scratch or needs to properly administrate all the informal compliance processes in the company, the introduced model of the a Intragroup Compliance Agreement may help him/her to handle the Compliance as a inherent part of the business and and to consider it as a "showstopper and troublemaker" in the company. 


\section{The International Journal}

The International Journal
TAINABILITY ISSUES

ISSN 2345-0282 (online) http://jssidoi.org/jesi/

2019 Volume 6 Number 3 (March)

http://doi.org/10.9770/jesi.2019.6.3(10)

Further important aspect of the IGCA reflects the constant internationalization of the environment, increasing competition and for efficiency reasons, it is quite common that multinational enterprises provide different services within the group. In addition, the creation of intragroup service centers to centralize the service offering in the group has been the trend of the recent years. Thus, there is no need for group members to separately outsource different services from third parties including investigation e.g.. Usually, these services are of supportive nature, which are not directly related to the group's core business, for example HR, accounting and legal services including investigation and compliance management consulting services. Also, it is quite common that the main function of the parent company is a holding activity and offering a management service or specifically trained, educated personel to the group members, capable to conduct investigation in discret, impartial and professional manner.

\section{Aknowledgements}

This work was supported by the Slovak Research and Development Agency under the contract No. APVV-150267.

\section{References:}

Adams, M.; Law, T. 1989. Business, and Society; 2. ed. Homewood: Richard D. Irwin, Inc., ISBN 0-256-07374-0; 1989 , p. 891.

Anderson, J.H.; Gray, C.H. 2006. W.; Anticorruption in Transition 3, Who is Succeeding...and why?; The World Bank, p. 105

Aplikace $\S 8$ odst. 5 zákona o trestní odpovědnosti právnických osob a řízení proti nim - Průvodce novou právní úpravou pro státní zástupce [Application $\S 8$ par. 5 of the Act on Criminal Liability of Legal Entities and Proceedings against them - Guide to New Legislation for Public Prosecutors] Supreme state attorney, Brno, Czech Republic on October 29th, 2016. available [online] na: httpwww.nsz.cz/index.php/cs/tiskove-zpravy/1800-pi-stihani-pravnickych-osob-pome-statnim-zastup://cm-nova-metodika. [on. September 29th. 2017]

A Resource Guide to the U.S. Foreign Corrupt Practices Act, USDOJ, Novemeber 2012, p. 82 Available at: https://www.justice.gov/sites/default/files/criminal-fraud/legacy/2015/01/16/guide.pdf

Deutscher Corporate Governance Codex issued on February 7th 2017, available at: http://www.dcgk.de/en/code.html

Fenyk, J.; Smejkal, L.; Zákon o tresttní odpovědnosti právnických osob a řízení proti nim- komentár̆ [ Act on Punitive Liability of Legal Entities and Proceedings against them- Commentary], Wolters Kluwer, 2012, ISBN: 978-80-7357-720-9, p. 45

Financial Action Task Force, Carribean Action Task Force, 40 recoomendations of the FATF available at: http://www.fatfgafi.org/publications/fatfrecommendations/documents/fatf-recommendations.html

Gray, C.H.W.; Hellman, J.; Rytterman, R. 2004. Anticorruption in Transition 2, Corruption in Enterprise-State Interactions in Europe and Central Asia 1999-2002; The World Bank, p. 81.

Kordík, M.; Kurilovská, L.; Intra Group Compliance Agreement as a tool to manage the risks in the daughter companies, Enterpreneurship and Sustainability Center, Enterpreneurship and Sustainability Issues n. 4/2018, ISSN (online) 2345-0282 p.1008-1019, https://doi.org/10.9770/jesi.2018.5.4(21) 
The International Journal

ENTREPRENEURSHIP AND SUSTAINABILITY ISSUES

ISSN 2345-0282 (online) http://jssidoi.org/jesi/

2019 Volume 6 Number 3 (March)

http://doi.org/10.9770/jesi.2019.6.3(10)

McCarthy, F. William John W. Bagby. 1990. The Legal Environment of Business. - Boston: Richard D. Irwin, Inc., ISBN 0-256-08482-3, p. 790

Metzger, Michael B, Business Law and the Regulatory Environment: Concepts and Case; 8. ed. - Homewood: IRWIN, 1992; ISBN 0-25608700 p. 1500

Muller, W. H.; Kalin, Ch.; Goldsworth, J. G. 2007. Anti-money Laundering- International law and Practice., John Waley and Sons Ltd., p. 813.

Plea agreement, Kelogg, Brown, Root LLC. vs. USDOJ, p.25 available at: https://www.justice.gov/sites/default/files/criminalfraud/legacy/2011/02/16/02-11-09kbr-plea-agree.pdf. On August 28th, 2018

Reitzel; J. David. 1990. Contemporary Business Law: Principles and Cases; 4. ed. New York: McGraw-Hill Publishing Comp., ISBN 007-051905-6; p.225.

Statement of Offense, Siemens AG vs. USDOJ, n: 1.08/367, https://www.justice.gov/sites/default/files/criminalfraud/legacy/2013/05/02/12-15-08siemens-statement.pdf. Available on: August 28th, 2018

Stessens, G. 2002. Money laundering. A new international Law enforcement model; Cambridge University Press, p. 460

Turayová, Y.; Tobiašová, L.; Kol, A. 2014. Trestná zodpovednost’ právnických osôb- Medzinárodné a európske aspekty, právno-teoretické východiská [Criminal liability of legal entities - International and European aspects, legal and theoretical bases], Wolters Kluwer, Bratislava, 2014, ISBN: 978-80-7160-383-2; p.82

United States Sentencing Commission Guideline Manual on November 1st 2014, available at: https://www.ussc.gov/sites/default/files/pdf/guidelines-manual/2013/manual-pdf/2013_Guidelines_Manual_Full.pdf. on: August 28th, 2018

\section{Marek KORDÍK}

ORCHID ID: https://orcid.org/0000-0002-4290-8354

\section{Lucia KURILOVSKA}

ORCHID ID: https://orcid.org/0000-0002-1008-9067

Copyright (C) 2019 by author(s) and VsI Entrepreneurship and Sustainability Center

This work is licensed under the Creative Commons Attribution International License (CC BY).

http://creativecommons.org/licenses/by/4.0/

(c) (†) Open Access 